\title{
Effects of Salinity on Soil Properties of Coastal Areas of (Babuganj, Bakerganj, Gournadi and Kalapara) in Bangladesh
}

\author{
Raja Md. Masum ${ }^{1 *}$, N. Naher ${ }^{2}$, A. K. Paul ${ }^{3}$ and A. K. M. M. Alam ${ }^{4}$ \\ ${ }^{1}$ Dept. of Agroforestry and Environmental Science, ${ }^{2}$ Dept. of Agroforestry and Environmental Science, ${ }^{3}$ Dept. of Soil Science, \\ Sher-e-Bangla Agricultural University, Dhaka (12 07), Bangladesh \\ ${ }^{4}$ PRC, BARI, Gazipur (17 01), Bangladesh
}

\section{Corresponding Author}

Raja Md. Masum

e-mail: nazmunsau@yahoo.com

\author{
Article History \\ Article ID: AR1840b \\ Received in $2^{\text {nd }}$ September, 2017 \\ Received in revised form $28^{\text {th }}$ September, 2017 \\ Accepted in final form $7^{\text {th }}$ October, 2017
}

\begin{abstract}
Bangladesh is highly vulnerable to sea level rise and salinity became a serious problem for agriculture all over the world. Soil salinity affects the parameters in soil and it is one of the major causes of decrease in the organic matter and nitrogen level in the southwestern part of Bangladesh. So, a field study was conducted to determine the effects of salinity on soil properties at Babuganj, Bakerganj, Gournadiupazilas of Barisal and Kalaparaupazilaof Patuakhali district of Bangladesh during the period of July to September 2016. Soil sampling was done by random sampling method at 0-50 cm and 50-100 cm depth. The dominant soil textural classes in the saline areas were silty clay. The soils $\mathrm{pH}$ of the surface horizon was slightly lower than those of the subsoil. Cation Exchange Capacity (CEC) of all these soils varied from 12.83 to 20.92 meq $100 \mathrm{~g} \mathrm{~g}^{-1}$ soil. Electrical conductivity (EC) varied from $1.23 \mathrm{dS} / \mathrm{m}$ to $6.6 \mathrm{dS} / \mathrm{m}$ at Babuganj, Bakergnaj and Gournadi and moderately saline at Kalapara. The organic matter content was medium to high (0.62 to 1.6)\% at Kalapara and Bakerganj but pretty low (0.39 to 1.03)\% at Babuganj and Gournadi. Nutrient deficiencies for total nitrogen were quite dominant in the study areas. It was found that the clay content was the most fundamental property to control chemical properties of soils. From the correlation matrix it was found that organic matter showed significant negative relationship with CEC and Exchangeable $\mathrm{Na}, \mathrm{K}$, $\mathrm{Ca}$ and Mg showed mostly significant negative relationship with OM. Exchangeable sodium, potassium, calcium and magnesium were in high level and the dominant water soluble anions were $\mathrm{Cl}^{-}$and $\mathrm{SO}_{4}^{2-}$.
\end{abstract}

Keywords: Coastal areas, salinity, soils, exchangeable cations

\section{Introduction}

Salinity being a major problem is worldwide. Bangladesh is experienced with this problem and the southern part of the country also affected by salinity. Coastal areas of Bangladesh cover more than $30 \%$ of the cultivable lands of the country (Islam, 2006. According to the coastal zone policy (CZPo, 2005) of the Government of Bangladesh, 19 districts out of 64 are in the coastal zone covering a total of 147 upazilas of the country. Central coastal zone extends from Feni river estuary to the eastern corner of the Sundarbans, covering Noakhali, Barisal, Bhola and Patuakhali districts. The zone receives a large volume of discharge from the Ganges-BhrahmputraMeghna river system, forming high volume of silty deposition. More than $70 \%$ of the sediment load of the region is silt; with an additional $10 \%$ sand (Allison et al., 2003). The coastal saline are lies about 1.5 to $11.8 \mathrm{~m}$ above mean sea level. The Ganges River meander flood plain systems are standing higher than the adjoining tidal lands. The tidal flood plain has a distinctive, almost level landscape crossed by innumerable interconnecting tidal rivers and creeks. The estuarine islands are constantly changing shape and position as result of river erosion and new alluvial deposition. The lands of coastal area become saline as it comes in contact with sea water by continuous inundation during high tides and ingress of sea water through cracks and sometimes cyclone induced storm surge. The severity of salinity is increasing in the coastal area during winter with the drying of soil (Naher et al., 2011). During rabi season large area remain fallow due to lack of irrigation water and higher level of salinity. Again the coastal belts remain inundated with range of $60 \mathrm{~cm}$ to $80 \mathrm{~cm}$ from May to September limiting the cultivation of crops except some local rice varieties, covering $60 \%$ of total cultivated land (Karim et al., 1998).

Soil with an electrical conductivity of saturation extracts above $4 \mathrm{dSm}^{-1}$ is called saline soil. The proportions of cations and anions in the natural soil water solution are a function of soil type, climate and land use. The concentration and relative proportions of these salts play a critical role in the salinity 
hazard of soil. On a global scale, nearly $40 \%$ of the earth's land surface is potentially endangered by salinity problems. Salinity areas are increasing day by day. It affects negatively on plant growth and yields. The severity of salinity problem in Bangladesh increases with the desiccation of the soil. It affects crops depending on degree of salinity at the critical stages of growth, which reduces yield and in severe cases total yield is lost. Soil reaction values $(\mathrm{pH})$ in coastal regions range from 6.0-8.4 (Haque, 2006; Naher et al., 2011). During the wet monsoon the severity of salinity is reduced due to dilution of the salt in the root-zone of the standing crop. Salinity distributions in the coastal region of Bangladesh vary location to location. Both water and soil salinity along the coast will be increased with the rise in sea level, destroying normal characteristics of coastal soil and water. Salinity causes unfavorable environmental and hydrological situation restricting the normal crop production throughout the year. So the study was conducted to study theeffects of salinity
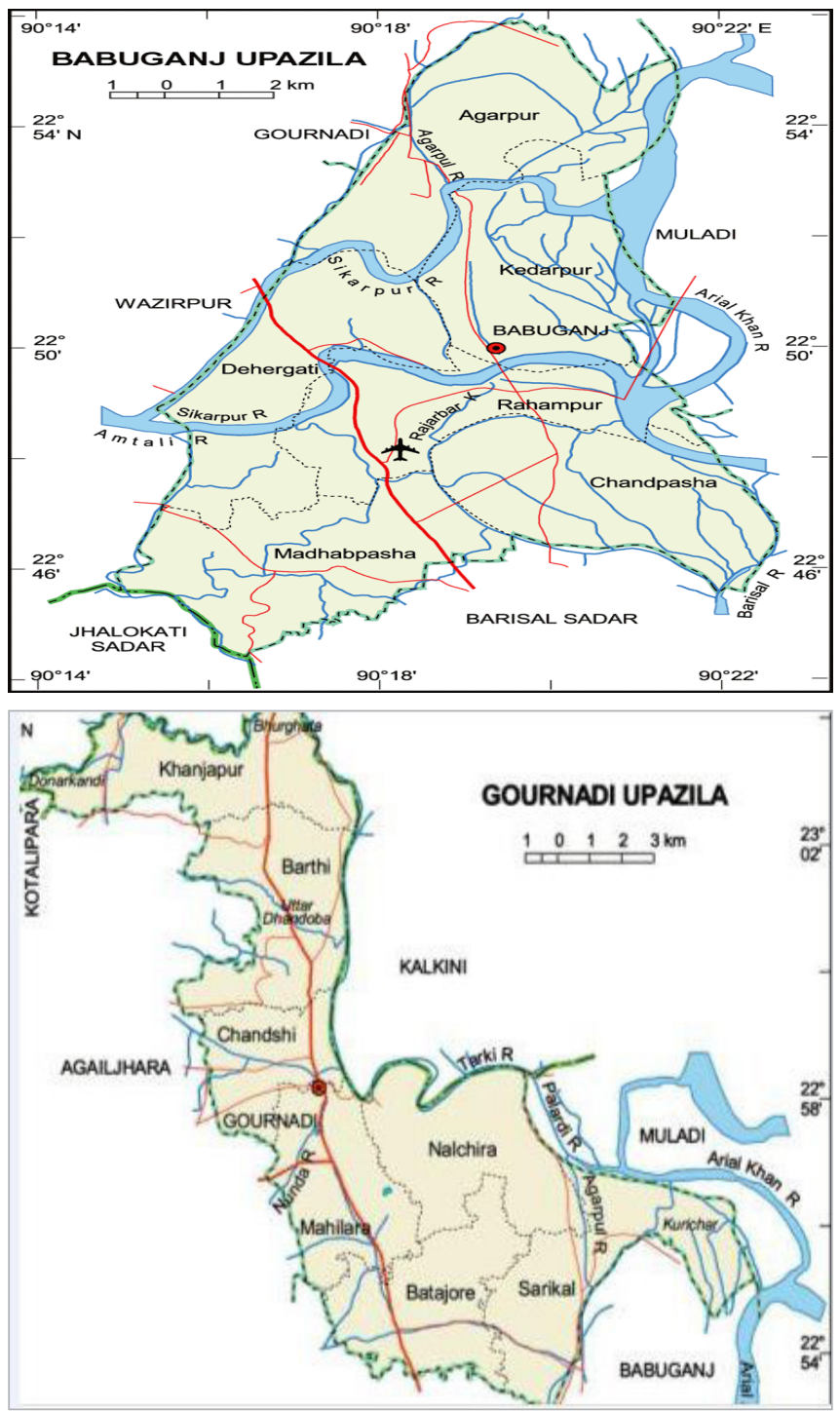

on physico-chemical properties of soil salinity at Babuganj, Bakerganj, Gournadi and Kalapara saline areas of Bangladesh.

\section{Materials and Methods}

\subsection{Study area}

A field survey was carried out at Babuganj, Bakerganj and Gournadiupazilas in Barisal district and Kalapara is an upazilaof Patuakhali district in Barisal in Bangladesh during JulySeptember, 2016. Babuganj is located at $22.8319^{\circ} \mathrm{N} 90.3222^{\circ} \mathrm{E}$. Bakerganj at $22.5500^{\circ} \mathrm{N} 90.3389^{\circ} \mathrm{E}$.Gournadi at $22.9736^{\circ} \mathrm{N}$ $90.2306^{\circ} \mathrm{E}$. Kalapara at 21.98610N 90.24220E (Figure 1).

Barisal and Kalapara include mainly Ganges Tidal floodplain and their sub regions are saline, non calcareous, and the main soil types are loamy and clayey. Mainly four categories of salinity existing in the coastal saline areas and the range are from $\mathrm{S}_{1}$ to $\mathrm{S}_{4}$. Soil occurring in the coastal areas of Bangladesh shows a wide variation in salinity (Table 1 ). Maximum and
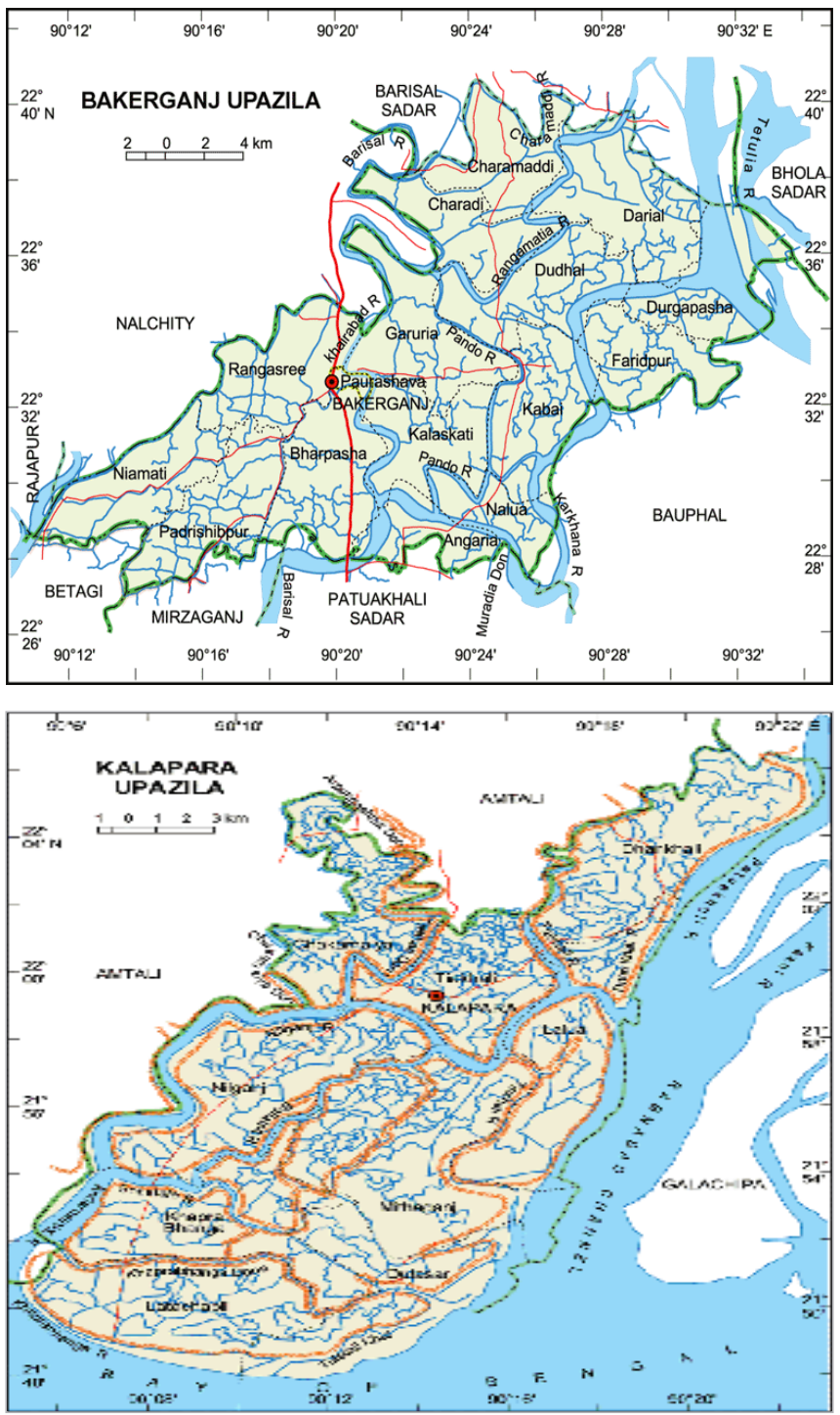

Figure 1: Study areas at Babuganj, Bakerganj and Gournadiupazilas in Barisal district and Kalaparaupazila in Patuakhali district of Bangladesh 
Table 1: Distribution and extent of different categories of soil salinity in the studied saline areas of Bangladesh

\begin{tabular}{|c|c|c|c|c|c|c|c|}
\hline \multirow[t]{5}{*}{ Locations } & \multirow{5}{*}{$\begin{array}{l}\text { Total area } \\
\text { (ha) }\end{array}$} & \multirow{5}{*}{$\begin{array}{c}\text { Total saline } \\
\text { area (ha) }\end{array}$} & \multirow{5}{*}{$\begin{array}{l}\text { Percent of } \\
\text { saline area }\end{array}$} & \multicolumn{4}{|c|}{ Salinity categories } \\
\hline & & & & $\mathrm{S}_{1}$ & $\mathrm{~S}_{2}$ & $\mathrm{~S}_{3}$ & $\mathrm{~S}_{4}$ \\
\hline & & & & $2.1-4\left(\mathrm{ds} \mathrm{m}^{-1}\right)$ & 4.1-8 $\left(\mathrm{ds} \mathrm{m}^{-1}\right)$ & $8.1-15\left(\mathrm{ds} \mathrm{m}^{-1}\right)$ & $>15\left(\mathrm{ds} \mathrm{m^{-1 } )}\right.$ \\
\hline & & & & Slightly saline & Moderately saline & Saline & Strongly saline \\
\hline & & & & \multicolumn{4}{|c|}{ ( $\mathrm{Ha})$} \\
\hline Babuganj & 15,247 & 1470 & 10 & 1030 & 370 & 70 & 0 \\
\hline Bakerganj & 40,496 & 3350 & 9 & 3080 & 770 & 0 & 0 \\
\hline Gournadi & 14,417 & 2410 & 17 & 1930 & 480 & 0 & 0 \\
\hline Kalapara & 47,194 & 34,730 & 75 & 4770 & 10680 & 7240 & 7970 \\
\hline \multicolumn{8}{|c|}{ Source: Soil salinity in Bangladesh (SRDI) 2010} \\
\hline
\end{tabular}

minimum air temperatures vary from $30.6{ }^{\circ} \mathrm{C}$ to $25.2{ }^{\circ} \mathrm{C}$ in these areas. During the monsoon more than $90 \%$ of the total precipitation takes place. Total average rainfall is estimated to be maximum $2618 \mathrm{~mm}$ at Patuakhali and minimum 2188 $\mathrm{mm}$ at Barisal district annually

\subsection{Soils Used}

Soil samples were collected from 30 sites at $0.5 \mathrm{~km}$ distance and $0-50 \mathrm{~cm}, 50-100 \mathrm{~cm}$ depth by auger. Soil sampling was done by random sampling method. The soil samples were dried at room temperature, crushed, mixed thoroughly, sieved with $2 \mathrm{~mm}$ sieve and preserved in plastic bags for subsequent laboratory analyses.

\subsection{Analytical procedures}

Particle-size analysis was carried out by the hydrometer method as outlined by Bouyoucos (1927) and the textural classes were then by Marshall (1947) following the U.S. Department of Agriculture classification system. The $\mathrm{pH}$ was determined by a glass-electrode $\mathrm{pH}$ meter in the soil suspension having a soil: water ratio of $1: 2.5$, after $30-\mathrm{min}$ shaking. The electrical conductivity (EC) was measured by an EC meter in the soil suspension having a soil: water ratio of 1:5, after 30-min shaking. The organic carbon content was determined by the wet oxidation method as outlined by Nelson et al. (1982) and the organic matter content was calculated by multiplying the organic carbon content with a conventional factor of 1.724 . The total nitrogen content was determined by the micro-Kjeldhal digestion method. Cation exchange capacity (CEC) was determined by the sodium saturation method as described by, Chapman, (1965).Exchangeable calcium, sodium and potassium were extracted from soil using $1 \mathrm{M} \mathrm{CH}_{3} \mathrm{COONH}_{4}$ and their concentrations in the extract were directly determined by a flame photometer. Exchangeable magnesium was extracted by Diethylene Triamine Penta Acitate (DTPA) solution and its concentration in the extract was determined directly by an atomic absorption spectrophotometer (AAS). Water soluble ion $\mathrm{Cl}^{-}$was determined by $0.01 \mathrm{~N} \mathrm{AgNO}_{3}$ titration method and $\mathrm{SO}_{4}=$ Determined by turbidimetric method.

Exchangeable Sodium Percentage (ESP) and Sodium Adsorption Ratio (SAR) were determined by-
$\mathrm{ESP}=\frac{\text { Exchangeable } \mathrm{Na}+}{\mathrm{CEC}} \times 100$

$\mathrm{SAR}=\left(\right.$ sodium $^{+} /$calcium $^{+}+$magnesium +$\left.) / 2\right)^{1 / 2}$

Collected data were processed and analyzed by using SPSS16.0 version software and MS excel 2007. Pearson's product moment correlation coefficient was computed to explore the correlation matrix.

\section{Results and Discussion}

Salinity has an adverse effect on soil physical and chemical properties. Saline soil contains an excess of soluble salts, especially sodium chloride. The proportions of cations and anions in the natural soil water solution are a function of soil type. The physico-chemical properties and salt characteristics of the soils of Babuganj, Bakerganj, Gournadi and Kalapara regions under this study are below:

\subsection{Soil properties}

\subsubsection{Particle size distribution}

Data presented in the Table 2 indicated that silt and clay are the dominant fractions of the study areas and the textural classes are silty clay. The clay and silt contents were increased with depth at Babuganj, Gournadi and Kalapara while, sand content was decreased. Naher et al. (2011) found the same

Table 2: Physical properties of different soils in studied areas of Bangladesh

\begin{tabular}{|c|c|c|c|c|c|}
\hline \multirow[t]{2}{*}{ Locations } & \multirow{2}{*}{$\begin{array}{c}\text { Depth } \\
\text { (cm) }\end{array}$} & \multicolumn{3}{|c|}{ Particle size distribution (\%) } & \multirow[t]{2}{*}{ Texture } \\
\hline & & Sand & Silt & Clay & \\
\hline \multirow[t]{2}{*}{ Babuganj } & $0-50$ & 10 & 53 & 37 & Silty clay \\
\hline & $50-100$ & 9 & 50 & 41 & Silty clay \\
\hline \multirow[t]{2}{*}{ Bakerganj } & $0-50$ & 10 & 52 & 38 & Silty clay \\
\hline & $50-100$ & 9 & 53 & 38 & Silty clay \\
\hline \multirow[t]{2}{*}{ Gournadi } & $0-50$ & 10 & 53 & 37 & Silty clay \\
\hline & $50-100$ & 9 & 52 & 39 & Silty clay \\
\hline \multirow[t]{2}{*}{ Kalapara } & $0-50$ & 12 & 51 & 37 & Silty clay \\
\hline & $50-100$ & 9 & 52 & 39 & Silty caly \\
\hline
\end{tabular}


result at Satkhira and Kalapara of Bangladesh.

\subsection{Chemical properties}

\subsubsection{Soil reaction}

The $\mathrm{pH}$ value of the topsoil at Babuganj ranged from 7.4-7.7 in 50-100 cm depth which is moderately alkaline. At Bakerganj, the $\mathrm{pH}$ values in 0-50 cm depth were 7.4-7.5 in $50-100 \mathrm{~cm}$ depth which is slightly alkaline. At Gournadi, the $\mathrm{pH}$ values in $0-50 \mathrm{~cm}$ depth were $8.0-8.2$ in $50-100 \mathrm{~cm}$ depth which is strongly alkaline. At Kalapara, the $\mathrm{pH}$ values in $0-50 \mathrm{~cm}$ depth were 5.90 to 6.20 which is slightly acidic and in 50-100 cm depth in this area the $\mathrm{pH}$ ranged from 6.44 to 7.2 that isneutral. In most of the soils, $\mathrm{pH}$ increased with depth which is similar to the report published by SRDI, 2000 in Borguna district of Bangladesh. The higher $\mathrm{pH}$ values of the soils are likely micronutrient deficiency and Phosphate fixation problem.

\subsubsection{Total nitrogen}

The total nitrogen content of the topsoil was generally low to occasionally high ranging from 0.06 to $0.09 \%$ at Babugnaj and Bakerganj, 0.09 to $0.1 \%$ at Gournadi and 0.07 to $0.09 \%$ at Kalapara (Table 3). The total nitrogen content of the soil from Babuganj and Bakerganj were low to very low level than that of the soils from Gournadi and Kalapara according to the grading of (BARC, 1997). Nitrogen content of the surface horizon was higher than that of subsoil. The poor nitrogen status of salt affected soil was due to high rates of decomposition of organic matter and inadequate application of organic matter in terms of manure, compost etc. and high volatilization of ammonium nitrogen. Naher et al. (2011); Portch and Islam, (1984) also found that $100 \%$ of the soils were deficient in available nitrogen, which was similar to the present findings.

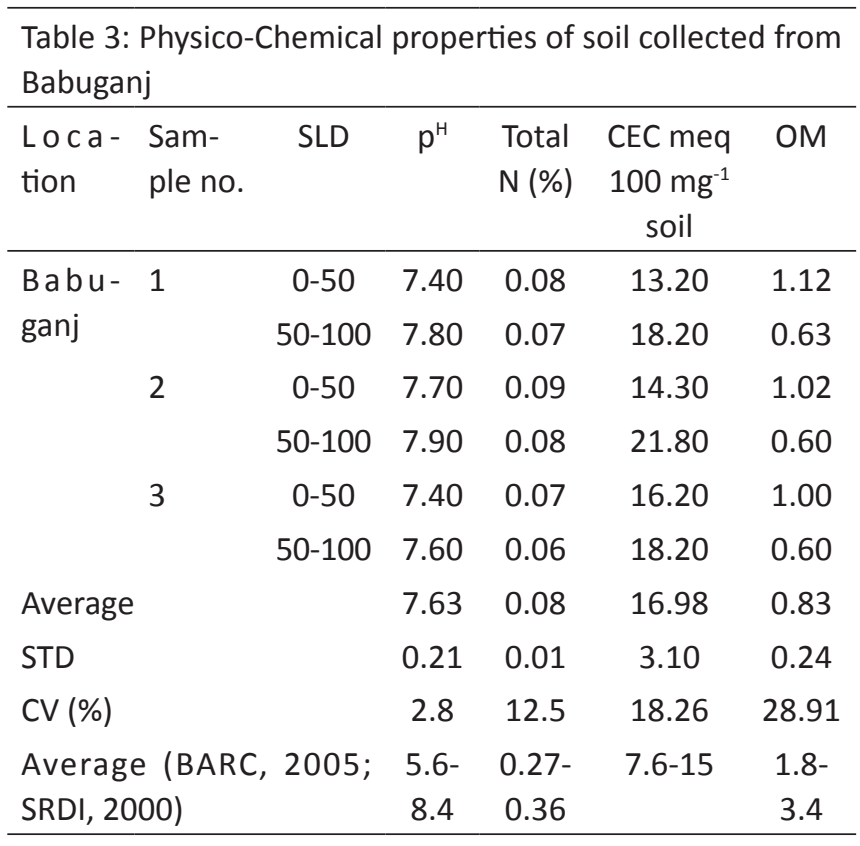

SLD: Soil layer depth (cm); OM: Organic matter (\%)

\subsubsection{Cation exchange capacity (CEC)}

Cation Exchange Capacity (CEC) of soils at different horizons varies from 13.2 to 21.8 meq $100 \mathrm{~g}^{-1}$ soil at Babuganj 16.6 to 20.8 meq $100 \mathrm{~g}^{-1}$ soil at Bakerganj 14.8 to 21.3 meq 100 $\mathrm{g}^{-1}$ soil at Gournadi and 12.8 to $21.0 \mathrm{meq} 100 \mathrm{~g}^{-1}$ soil at Kalapara. CEC of all this soils varies from 12.8 to 21.0 meq $100 \mathrm{~g}^{-1}$ soil expressing medium to high status according to the (BARC, 2012). Naher et al. (2011) found 12.8 to $27.2 \mathrm{meq}$ $100 \mathrm{~g}^{-1}$ soil and 12.8 to 21.0 meq $100 \mathrm{~g}^{-1}$ soil in Satkhira and Kalaparaupazila respectively.

\subsubsection{Organic matter (OM)}

From the Table 5 and table 6 organic matter range was 1.0 to $1.12 \%$ at Babuganj and Bakerganj and Table 3 and Table 4 it is seen that this range was 1.02 to $1.12 \%$ at Gournadi and 0.09 to $1.89 \%$ at Kalapara. Top soil organic matter content in almost all the soils collected from Kalapara were found very low mainly due to the lower topographic position of the soils. Organic matter content gradually decreases with depth may be due to the presence of buried mineral and organic horizons. SRDI (1993); Karim et al. (1990); Naher et al. (2011) and Anwar (1993) reported that the organic matter content ranged between 0.10 to 1.00 and 1.15 to $2.27 \%$ in two salt affected soils of Bangladesh.

\subsubsection{Salt characteristics}

Soil salinity of different horizons normally ranged from 1.05 to $1.23 \mathrm{dS} / \mathrm{m}$ at Babuganj, 1.31 to $1.42 \mathrm{dS} / \mathrm{m}$ at Bakerganj which is non saline. But at Gournadi it was 1.78 to $2.68 \mathrm{dS} / \mathrm{m}$ which denotes very slightly saline. At Kalapara the ECe ranged from 4.1 to $6.6 \mathrm{dS} / \mathrm{m}$ which is under slightly saline. The higher ECe value found at the surface horizon followed by decrease with depth can be attributed to flooding with saline water or

Table 4: Physico-chemical properties of soil collected from Bakerganj

\begin{tabular}{|c|c|c|c|c|c|c|}
\hline $\begin{array}{l}\text { Loca- } \\
\text { tion }\end{array}$ & $\begin{array}{l}\text { Sample } \\
\text { no. }\end{array}$ & SLD & $\mathrm{p}^{\mathrm{H}}$ & $\begin{array}{l}\text { Total } \\
\text { N (\%) }\end{array}$ & $\begin{array}{c}\text { CEC meq } \\
100 \mathrm{mg}^{-1} \\
\text { soil }\end{array}$ & OM \\
\hline \multirow{6}{*}{$\begin{array}{l}\text { Babu- } \\
\text { ganj }\end{array}$} & \multirow[t]{2}{*}{1} & $0-50$ & 7.4 & 0.09 & 17.2 & 1.02 \\
\hline & & $50-100$ & 7.5 & 0.07 & 20.8 & 0.60 \\
\hline & \multirow[t]{2}{*}{2} & $0-50$ & 7.4 & 0.08 & 16.6 & 1.12 \\
\hline & & $50-100$ & 7.8 & 0.06 & 19.6 & 0.63 \\
\hline & \multirow[t]{2}{*}{3} & $0-50$ & 7.5 & 0.09 & 17.3 & 1.0 \\
\hline & & $50-100$ & 7.7 & 0.08 & 18.2 & 0.60 \\
\hline \multicolumn{3}{|c|}{ Average } & 7.6 & 0.07 & 18.28 & 0.83 \\
\hline \multicolumn{3}{|l|}{ STD } & 0.16 & 0.01 & 1.62 & 0.24 \\
\hline \multicolumn{3}{|l|}{ CV (\%) } & 2.10 & 14.28 & 8.86 & 28.92 \\
\hline \multicolumn{2}{|c|}{$\begin{array}{l}\text { Average (BARC, } \\
\text { SRDI, 2000) }\end{array}$} & 2005 & $\begin{array}{l}5.6- \\
8.4\end{array}$ & $\begin{array}{l}0.27- \\
0.36\end{array}$ & 7.6-15 & $\begin{array}{l}1.8- \\
3.4\end{array}$ \\
\hline
\end{tabular}

SLD: Soil layer depth (cm); OM: Organic matter (\%) 


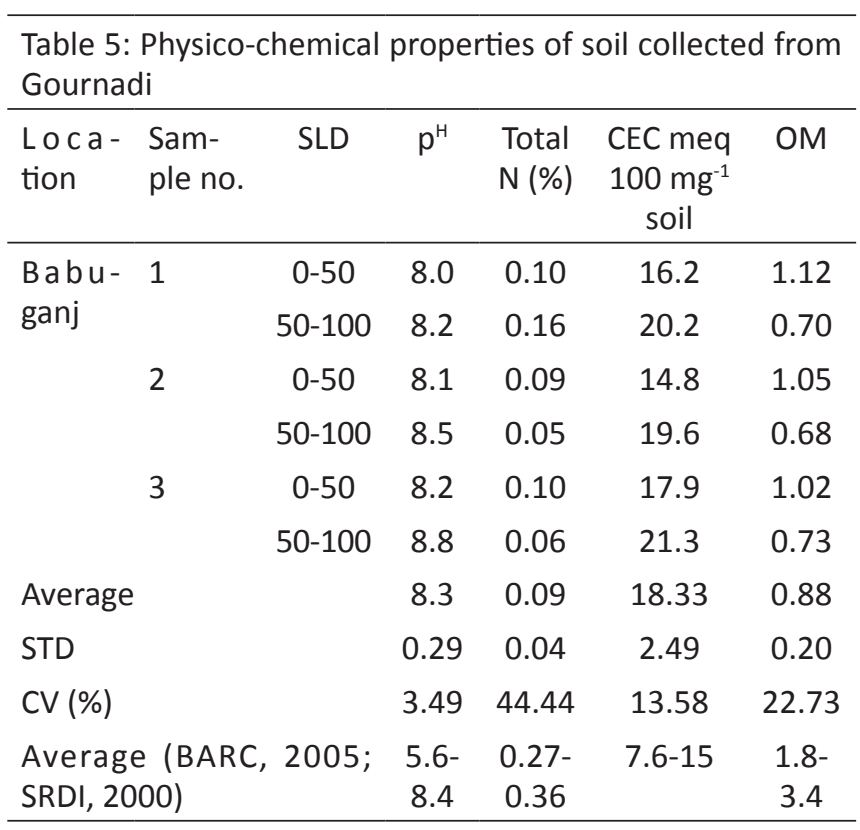

SLD: Soil layer depth (cm); OM: Organic matter (\%)

Table 6: Physico-Chemical properties of soil collected from Kalapara

\begin{tabular}{|c|c|c|c|c|c|c|}
\hline $\begin{array}{l}\text { Loca- } \\
\text { tion }\end{array}$ & $\begin{array}{l}\text { Sam- } \\
\text { ple no. }\end{array}$ & SLD & $p^{H}$ & $\begin{array}{l}\text { Total } \\
\mathrm{N}(\%)\end{array}$ & $\begin{array}{c}\text { CEC meq } \\
100 \mathrm{mg}^{-1} \\
\text { soil }\end{array}$ & OM \\
\hline \multirow{6}{*}{$\begin{array}{l}\text { Babu- } \\
\text { ganj }\end{array}$} & \multirow[t]{2}{*}{1} & $0-50$ & 6.20 & 0.09 & 12.8 & 0.90 \\
\hline & & $50-100$ & 6.44 & 0.08 & 20.80 & 0.62 \\
\hline & \multirow[t]{2}{*}{2} & $0-50$ & 5.92 & 0.08 & 12.70 & 1.87 \\
\hline & & $50-100$ & 6.49 & 0.07 & 20.60 & 0.58 \\
\hline & \multirow[t]{2}{*}{3} & $0-50$ & 5.90 & 0.09 & 13.0 & 1.89 \\
\hline & & $50-100$ & 7.20 & 0.08 & 21.0 & 0.60 \\
\hline \multicolumn{3}{|l|}{ Average } & 6.36 & 0.08 & 16.82 & 1.07 \\
\hline \multicolumn{3}{|l|}{ STD } & 0.48 & 0.007 & 4.37 & 0.63 \\
\hline \multicolumn{3}{|l|}{ CV (\%) } & 7.55 & 8.75 & 25.98 & 58.88 \\
\hline \multicolumn{2}{|c|}{$\begin{array}{l}\text { Average (BARC, } \\
\text { SRDI, 2000) }\end{array}$} & 2005 & $\begin{array}{l}5.6- \\
8.4\end{array}$ & $\begin{array}{l}0.27- \\
0.36\end{array}$ & $7.6-15$ & $\begin{array}{l}1.8- \\
3.4\end{array}$ \\
\hline
\end{tabular}

SLD: Soil layer depth (cm); OM: Organic matter (\%)

accumulation of salts through upward capillary movement of saline ground water.

\subsubsection{Exchangeable sodium content}

It was observed that the exchangeable sodium content for Babuganj varied from 1.25 to 2.1 meq $100 \mathrm{~g}^{-1}$ soils, 1.2 to 2.3 meq $100 \mathrm{~g}^{-1}$ soils at Bakerganj, 1.63 to 2.15 meq $100 \mathrm{~g} \mathrm{~g}^{-1}$ soils at Gournadi and Kalapara varied from 1.67 to $2.2 \mathrm{meq}$ $100 \mathrm{~g}^{-1}$ soils (Table 7). When sodium salts reach at high levels the soils may disperse and the soil pores become blocked with the subsequent capture of the colloids (Robert, 2006). Such physical blocking of the soil pores cannot be reversed chemically and the permeability of the effluent application area will be reduced (Rengasamy and Olsson, 1993).

\subsubsection{Exchangeable potassium content}

The exchangeable potassium content of the soils of Babuganj, Bakerganj, Gournadi and Kalapara varied mainly based on the clay content. At Babuganj this range was 0.68 to $1.0 \mathrm{meq}$ $100 \mathrm{~g}^{-1}$ soil, 0.7 to $1.35 \mathrm{meq} 100 \mathrm{~g}^{-1}$ soil at Bakerganj, 0.67 to 1.0 meq $100 \mathrm{~g} \mathrm{~g}^{-1}$ soil at Gournadi and at Kalapara it was 0.57 to 1.10 meq $100 \mathrm{~g}^{-1}$ soil. All of these ranges were very high. Naher et. al. (2011) found that the exchangeable potassium content of the soils of Asasuni ranged from 0.45 to 1.45 meq $100 \mathrm{~g} \mathrm{~g}^{-1}$ soil and at Kalapara it was 0.57 to $1.10 \mathrm{meq} 100 \mathrm{~g} \mathrm{~g}^{-1}$ soil.

\subsubsection{Exchangeable calcium content}

The exchangeable calcium contents of the soils for Babuganj were 5.78 to $10.5 \mathrm{meq} 100 \mathrm{~g} \mathrm{~g}^{-1}$ soil, and 6.1 to $9.98 \mathrm{meq}$ $100 \mathrm{~g}^{-1}$ soil at Bakerganj, 6.53 to 10.63 meq $100 \mathrm{~g}^{-1}$ soils at Gournadi and for Kalapara, ranged from 6.73 to 10.75 meq $100 \mathrm{~g}^{-1}$ soil. It is seen that the exchangeable calcium content at Babuganj, Bakerganj and Gournadiis medium to very high, and at Kalapara, the range is high to very high. (BARC, 2005) and Naher et al. (2011) showed the similar results atAsasuni which was medium to very high, and at Kalapara, the range high to very high.

\subsubsection{Exchangeable magnesium content}

Exchangeable magnesium content of these areas was in the very high level (Table 7). At Babuganj this range was 4.42 to 7.3 meq $100 \mathrm{~g}^{-1}$ soil, 3.98 to 7.7 meq $100 \mathrm{~g}^{-1}$ soil at Bakerganj, 4.38 to 7.48 meq $100 \mathrm{~g}^{-1}$ soil at Gournadi and at Kalapara it was ranged from 4.47 to 7.85 meq $100 \mathrm{~g}^{-1}$ soil. Naher et al. (2011) found that the Exchangeable magnesium content of Asasuni ranged from 4.0 to 6.0 meq $100 \mathrm{~g}^{-1}$ soil and from 4.47 to 7.85 meq $100 \mathrm{~g}^{-1}$ soil at Kalapara.

\subsubsection{Water soluble ions}

From the Table 9 it was shown that the water soluble ions $\mathrm{Cl}^{2}$ and $\mathrm{SO}_{4}=$ was ranged from 2.10 to $2.30 \mathrm{meq} \mathrm{I}^{-1}$ and 3.20 to $3.50 \mathrm{meq}^{-1}$ at Babuganj, 1.7 to $1.9 \mathrm{meq}^{-1}$ and 3.70 to 3.90 meq $\mathrm{l}^{-1}$ at Bakerganj, 1.8 to $2.10 \mathrm{meq} \mathrm{I}^{-1}$ and 3.60 to $4.10 \mathrm{meq}$ $\mathrm{I}^{-1}$ at Gournadi and 1.5 to $1.6 \mathrm{meq}^{-1}$ and 3.50 to $3.80 \mathrm{meq}^{\mathrm{l}^{-1}}$ at Kalapara. The amount of accumulated salt is found higher at the surface horizon. It decreases with depth and then increases again. The physical separation of soil particles results in sufficient distance between individual soil particles such that repulsive forces between like molecules exceed bonding forces and dispersion occurs

\subsubsection{Correlation matrix}

The correlation matrix for physical and chemical properties determined in the study areas have been given in the Table 8, 9,10 and 11 . It was found that the clay content was the most fundamental property to control chemical properties of these soils. Organic matter showed significant negative relationship with CEC. Exchangeable $\mathrm{Na}, \mathrm{K}, \mathrm{Ca}$ and $\mathrm{Mg}$ showed mostly significant negative relationship with OM. Exchangeable $\mathrm{Ca}$ Showed significant positive relationship with $\mathrm{pH}$ and mostly 
significant positive relationship with Exchangeable $\mathrm{K} \mathrm{Mg}$. Naher et al. (2011) found the same result at Kalapara and Asasuni.
3.2.12. Exchangeable sodium percentage (ESP) and sodium adsorption ratio (SAR)

Exchangeable Sodium Percentage ranged from $7.88 \%$ to

\begin{tabular}{|c|c|c|c|c|c|c|c|c|c|c|c|c|}
\hline \multirow[t]{2}{*}{ Locations } & \multirow[t]{2}{*}{ Depth cm } & \multirow{2}{*}{$\begin{array}{c}\mathrm{EC} \\
\mathrm{dS} / \mathrm{m}\end{array}$} & \multirow{2}{*}{$\begin{array}{l}\text { CEC meq } \\
100 \mathrm{~g}^{-1}\end{array}$} & \multicolumn{4}{|c|}{ Exchangeable Cationsmeq $100 \mathrm{~g}^{-1}$} & \multicolumn{3}{|c|}{ Watersoluble ions meq $\mathrm{l}^{-1}$} & \multirow[t]{2}{*}{ ESP } & \multirow[t]{2}{*}{ SAR } \\
\hline & & & & $\mathrm{Na}$ & $\mathrm{K}$ & $\mathrm{Ca}$ & $\mathrm{Mg}$ & $\mathrm{Cl}-$ & SO4 & & & \\
\hline \multirow[t]{2}{*}{ Babuganj } & $0-50$ & 1.23 & 14.6 & 1.25 & 0.68 & 5.78 & 4.42 & 2.10 & 3.20 & & 7.88 & 1.52 \\
\hline & $50-00$ & 1.05 & 19.7 & 2.1 & 1 & 10.5 & 7.3 & 2.30 & 3.50 & & 10.82 & 1.93 \\
\hline \multirow[t]{2}{*}{ Bakerganj } & $0-50$ & 1.42 & 15.8 & 1.2 & 0.7 & 6.1 & 3.98 & 1.7 & 3.70 & & 8.21 & 1.44 \\
\hline & $50-00$ & 1.31 & 19.4 & 2.3 & 1.35 & 9.98 & 7.7 & 1.9 & 3.90 & & 11.64 & 1.99 \\
\hline \multirow[t]{2}{*}{ Gournadi } & $0-50$ & 2.68 & 14.4 & 1.63 & 0.67 & 6.53 & 4.38 & 1.8 & 3.60 & & 10.99 & 1.52 \\
\hline & $50-00$ & 1.71 & 20.9 & 2.15 & 1 & 10.63 & 7.48 & 2.1 & 4.10 & & 10.28 & 1.95 \\
\hline \multirow[t]{2}{*}{ Kalapara } & $0-50$ & 6.6 & 12.8 & 1.67 & 0.57 & 6.73 & 4.47 & 1.5 & 3.50 & & 13.05 & 1.94 \\
\hline & $50-00$ & 4.1 & 20.8 & 2.20 & 1.10 & 10.75 & 7.75 & 1.6 & 3.80 & & 10.58 & 2.32 \\
\hline \multicolumn{13}{|c|}{ 8: Correlation matrix between soil physical and chemical properties of Babuganj } \\
\hline & & Clay & $\mathrm{pH}$ & $\mathrm{N}$ & & CEC & OM & $\mathrm{EC}$ & Ex Na & Exk & EX Ca & Ex Mg \\
\hline Clay & & 1 & & & & & & & & & & \\
\hline $\mathrm{pH}$ & & 0.411 & 1 & & & & & & & & & \\
\hline $\mathrm{N}$ & & 0.135 & 0.185 & 1 & & & & & & & & \\
\hline CEC & & -0.159 & 0.727 & -0.34 & & 1 & & & & & & \\
\hline OM & & -0.186 & -0.724 & 0.53 & & $-.893^{*}$ & 1 & & & & & \\
\hline $\mathrm{EC}$ & & $.930^{* *}$ & 0.465 & -0.2 & & 0.087 & -0.458 & 1 & & & & \\
\hline Ex $\mathrm{Na}$ & & 0.589 & 0.732 & -0.22 & & 0.488 & -0.729 & 0.732 & 1 & & & \\
\hline Ex K & & 0.189 & 0.59 & -0.65 & & $.835^{*}$ & $-.964^{* *}$ & 0.489 & 0.606 & 1 & & \\
\hline Ex Ca & & 0.256 & 0.724 & -0.49 & & $.857^{*}$ & $-.984^{* *}$ & 0.502 & 0.679 & $.968^{* *}$ & 1 & \\
\hline Ex Mg & & 0.295 & 0.7 & -0.53 & & $.826^{*}$ & $-.983^{* *}$ & 0.547 & 0.703 & $.973^{* *}$ & $.997^{* *}$ & 1 \\
\hline
\end{tabular}

Remarks: ${ }^{* *}$ and ${ }^{*}$ mean correlation significant at the 0.01 and 0.05 levels, respectively (2-tailed). Clay: clay percentage; N: total N content; CEC: cation exchange capacity; OM: organic matter content; Ec: electrical conductivity; Ex Na: exchangeable Na content; Ex K: exchangeable K content; Ex Ca: exchangeable Ca content; Ex Mg: exchangeable Mg content

Table 9: Correlation matrix between soil physical and chemical properties of Bakerganj

\begin{tabular}{|c|c|c|c|c|c|c|c|c|c|c|}
\hline & Clay & $\mathrm{pH}$ & $\mathrm{N}$ & CEC & OM & $\mathrm{EC}$ & $\mathrm{Ex} \mathrm{Na}$ & Exk & $\mathrm{EX} \mathrm{Ca}$ & Ex Mg \\
\hline Clay & 1 & & & & & & & & & \\
\hline $\mathrm{pH}$ & -0.43 & 1 & & & & & & & & \\
\hline $\mathrm{N}$ & 0.363 & -0.677 & 1 & & & & & & & \\
\hline CEC & -0.525 & 0.494 & -0.764 & 1 & & & & & & \\
\hline OM & 0.769 & -0.769 & 0.696 & $-.859^{*}$ & 1 & & & & & \\
\hline EC & 0.309 & -0.692 & 0.373 & -0.682 & 0.774 & 1 & & & & \\
\hline Ex Na & -0.703 & $.856^{*}$ & $-.866^{*}$ & 0.79 & $-.934^{* *}$ & -0.608 & 1 & & & \\
\hline Ex K & -0.66 & $.828^{*}$ & $-.908^{*}$ & $.820^{*}$ & $-.917^{*}$ & -0.585 & $.995^{* *}$ & 1 & & \\
\hline $\mathrm{Ex} \mathrm{Ca}$ & -0.682 & 0.798 & -0.808 & $.884^{*}$ & $-.982^{* *}$ & -0.744 & $.964^{* *}$ & $.961^{* *}$ & 1 & \\
\hline Ex Mg & -0.792 & 0.746 & -0.797 & $.857^{*}$ & $-.975^{* *}$ & -0.63 & $.971^{* *}$ & $.964^{* *}$ & $.982^{* *}$ & 1 \\
\hline
\end{tabular}

$* *, *$ : mean correlation significant at the $(p=0.01)$ and $(p=0.05)$ levels, respectively (2-tailed). 


\begin{tabular}{|c|c|c|c|c|c|c|c|c|c|c|}
\hline \multicolumn{11}{|c|}{ 10: Correlation matrix between soil physical and chemical properties of Gournadi } \\
\hline & Clay & $\mathrm{pH}$ & $\mathrm{N}$ & CEC & OM & EC & Ex Na & Exk & EX Ca & $\mathrm{Ex} \mathrm{Mg}$ \\
\hline Clay & 1 & & & & & & & & & \\
\hline $\mathrm{pH}$ & 0.62 & 1 & & & & & & & & \\
\hline $\mathrm{N}$ & -0.005 & -0.564 & 1 & & & & & & & \\
\hline CEC & 0.692 & 0.795 & -0.42 & 1 & & & & & & \\
\hline OM & -0.656 & -0.73 & 0.579 & $-.883^{*}$ & 1 & & & & & \\
\hline EC & -0.53 & -0.474 & -0.025 & $-.849^{*}$ & 0.65 & 1 & & & & \\
\hline Ex $\mathrm{Na}$ & $.822^{*}$ & 0.642 & -0.266 & 0.79 & $-.921^{* *}$ & -0.65 & 1 & & & \\
\hline Ex K & 0.8 & $.880^{*}$ & -0.506 & $.826^{*}$ & $-.917^{* *}$ & -0.525 & $.914^{*}$ & 1 & & \\
\hline Ex Ca & 0.733 & 0.721 & -0.451 & $.862^{*}$ & $-.984^{* *}$ & -0.672 & $.973^{* *}$ & $.938^{* *}$ & 1 & \\
\hline Ex Mg & $.829^{*}$ & 0.693 & -0.405 & $.859^{*}$ & $-.960^{* *}$ & -0.641 & $.973^{* *}$ & $.934^{* *}$ & $.978^{* *}$ & 1 \\
\hline \multicolumn{11}{|c|}{$* *, *$ : mean correlation significant at the $(p=0.01)$ and $(p=0.05)$ levels, respectively ( 2 -tailed) } \\
\hline \multicolumn{11}{|c|}{ 11: Correlation matrix between soil physical and chemical properties of Kalapara } \\
\hline & Clay & $\mathrm{pH}$ & $\mathrm{N}$ & CEC & OM & EC & Ex Na & Exk & EX Ca & $\mathrm{Ex} \mathrm{Mg}$ \\
\hline Clay & 1 & & & & & & & & & \\
\hline $\mathrm{pH}$ & -0.766 & 1 & & & & & & & & \\
\hline $\mathrm{N}$ & 0.188 & -0.413 & 1 & & & & & & & \\
\hline CEC & -0.531 & $.812^{*}$ & -0.707 & 1 & & & & & & \\
\hline OM & 0.576 & -0.785 & 0.476 & $-.821^{*}$ & 1 & & & & & \\
\hline EC & -0.519 & 0.13 & 0.005 & 0.075 & 0.279 & 1 & & & & \\
\hline Ex $\mathrm{Na}$ & -0.465 & $.868^{*}$ & -0.695 & $.964^{* *}$ & -0.801 & -0.038 & 1 & & & \\
\hline Ex K & 0.089 & -0.189 & -0.404 & 0.382 & -0.133 & 0.179 & 0.167 & 1 & & \\
\hline $\mathrm{Ex} \mathrm{Ca}$ & -0.542 & $.868^{*}$ & -0.592 & $.982^{* *}$ & -0.811 & 0.07 & $.974^{* *}$ & 0.264 & 1 & \\
\hline Ex Mg & -0.539 & 0.726 & -0.71 & $.981^{* *}$ & $-.822^{*}$ & 0.102 & $.896^{*}$ & 0.52 & $.936^{* *}$ & 1 \\
\hline
\end{tabular}

$* *, *$ : mean correlation significant at the $(p=0.01)$ and $(p=0.05)$ levels, respectively (2-tailed).

$10.82 \%$ at Babuganj, $8.21 \%$ to $11.64 \%$ at Bakerganj, $10.28 \%$ to $10.99 \%$ at Gournadi and $9.55 \%$ to $13.05 \%$ at Kalapara which were intermediate but acceptable is (<10\%) (Figure 2 and 3). The SAR value varies from 1.52 to 1.93 at Babuganj, 1.44 t0 1.99 at Bakerganj, 1.52 to 1.95 at Gournadi and 1.94 to 3.33 at Kalaparaupazila. The saline soils tend to have sodium adsorption ratios (SAR) less than 13 in their saturation extract

Depth $(\mathrm{cm})$ 0-50 ESP Depth (cm) 0-100 ESP

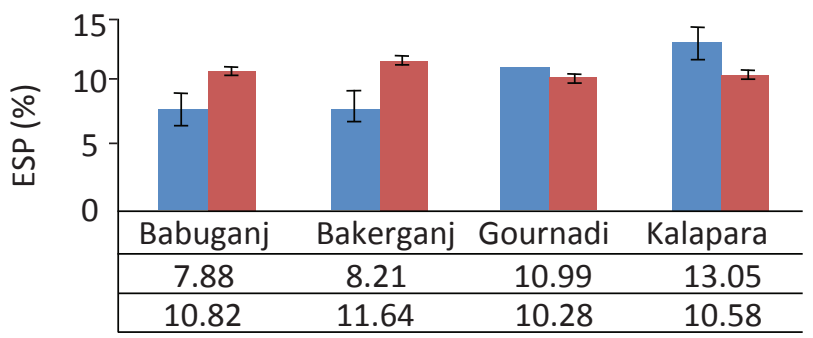

Figure 2: ESP of Babuganj, Bakerganj, Gournadi and Kalapara at different depths
Sodium adsorption ratio (SAR)

Depth $(\mathrm{cm})$ 0-50 ESP Depth $(\mathrm{cm})$ 0-100 ESP

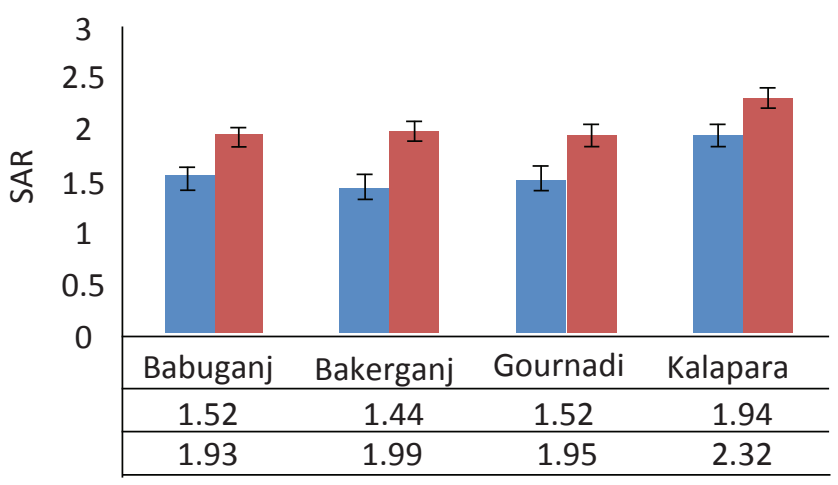

Figure 3: SAR (\%) of Babuganj, Bakerganj, Gournadi and Kalapara at different depths

and exchangeable sodium percentage (ESP) lower than 15. The SAR values of these areas are acceptable $(<10)$ during the study period. 


\section{Conclusion}

Coastal area in Bangladesh constitutes $20 \%$ of the country of which about $53 \%$ are affected by different degree of salinity. The texture of the study coastal areas was silty clay soil. In these areas Electrical conductivity (EC) varies from $1.23 \mathrm{dS} / \mathrm{m}$ to $6.6 \mathrm{dS} / \mathrm{m}$ expressing very slightly saline to slightly saline. Cation Exchange Capacity (CEC) of all these soils varies from 12.83 to 20.92 meq $100 \mathrm{~g}^{-1}$ soil expressing medium to high status. The organic matter content was pretty low to medium to high. The higher $\mathrm{pH}$ values of the soils are likely to create micronutrient deficiency problem. Hence, soil fertility should be improved based on the results obtained in the present study.

\section{References}

Allison, M.A., Khan, S.R., Goodbred, J.S.L., Kuehl, S.A., 2003. Stratigraphic evolution of the late Holocene GangesBrahmaputra lower delta plain, Sedimentary Geology 155, 317-342

Anwar, M.K., 1993. Evaluation of Some Physico-chemical Characteristics of Saline Soil. M.Sc. (Ag.) Thesis, Dept. Soil Science, BAU, Mymensingh, 1-79.

Bouyoucos, G.J., 1927. The hydrometer as a method for the mechanical analysis of soils. Soil Science 23, 343-353.

Chapman, H.D., 1965. Cation exchange capacity. In: Black, C.A. (Ed.), Methods of soil analysis. American Society of Agronomy, Inc., Madison, Wisconsin, 891-901.

CZPo, 2005. Coastal Zone Policy, Ministry of Water Resources, Government of the People's Republic of Bangladesh, Dhaka.

Haque, S.A., 2006. Salinity problems and crop production in coastal regions of Bangladesh rev. article. Pakistan of Journal of Botany 38(5), 1359-1365.

Islam, M.R., 2006. Managing Diverse Land Uses in Coastal Bangladesh: Institutional Approaches. In: Hoanh, C.T., Thong, T.P., Gowin, J.W., Hardy, B. (Eds.), Environment and Livelihoods in Tropical Coastal Zones, 237-248.
Karim, Z., Hussain, S.G., Ahmed, M., 1990. Salinity Problems and Crop Intensification in the Coastal Region of Bangladesh. Soil publication no. 33, Soils and Irrigation Division BARC, Farmgate, Dhaka, 1-22.

Karim, Z., Hussain, S.G., Ahmed, A.U., 1998. Climate Change Vulnerability of Crop Agriculture. In: Huq, S., Karim, Z., Asaduzzaman, M., Mahtab, F. (Eds.), Vulnerability and Adaptation to Climate Change for Bangladesh, Kluwer Academic Publishers, Dordrecht, 39-54.

Marshall, T.J., 1947. Mechanical composition of soils in relation to field description of texture. Commonwealth of Australia, Council for Scientific and Industrial Research, Bulletin 224, Melbourne (Australia), 20.

Naher, N., Uddin, M.K., Alam, A.K.M.M., 2011. Impacts of salinity on soil properties of coastal areas in Bangladesh, Agrivita 33(2), 3-10.

Nelson, D.W., Sommers, L.E., 1982. Total carbon, organic carbon, and organic matter. In: Methods of Soil Analysis, Part 2, $2^{\text {nd }}$ Ed., A.L. Page et al. (Ed.), Agronomy 9, 9611010. American Society of Agronomy, Inc. Madison, WI.

Olsen, S.R., Cole, C.V., Watanabe, F.S., Dean, A., 1954. Estimation of available phosphorus in soils by extraction with sodium bicarbonate. U.S. Department of Agriculture Circ., 929.

Portch, S., Islam, M.S., 1984. Nutrient status of some important agricultural soils of Bangladesh. In: Proceedings of the International Symposium on Soil Test Crop Response Correlation Studies. Bangladesh Agricultural Research Council and Soil Science Society of Bangladesh, Dhaka (Bangladesh), 97-106.

Rengasamy, P., 2006. World salinisation with emphasis on Australia. Journal of Experimental Botany 57, 10171023.

SRDI. 2000. Soil salinity in Bangladesh. Soil Resources Development Institute. Ministry of Agricultural, Dhaka-1215, 40-42. 